\title{
Instability and linkage of silver resistance, lactose fermentation, and colony structure in Enterobacter cloacae from burn wounds
}

\author{
D. I. ANNEAR, B. J. MEE, AND M. BAILEY \\ From the Department of Microbiology, Royal Perth Hospital, Western Australia and \\ the Department of Microbiology, the University of Western Australia, Perth, Western Australia
}

SYNOPSIS A strain of Enterobacter cloacae from a burn wound has displayed unstable resistance to silver nitrate and a linkage of this characteristic to that for rapid lactose fermentation and mucoid colony structure. Attempts to demonstrate transferability of these unstable determinants gave negative results.

The use of silver preparations for topical antimicrobial therapy in the Burns Unit of this Hospital has prompted routine screening of bacterial isolates for resistance to this metal.

During some early tests in this project two strains of Enterobacter cloacae were isolated which displayed high but unstable resistance to silver nitrate. Each was isolated from a different patient in the Burns Unit.

The two strains differed in that in one of them (Z173) silver resistance was linked to rapid lactose fermentation and to mucoid colony structure. In the other (Z147), the progeny were homogeneously slow lactose fermenters and yielded non-mucoid colonies. These features seemed of sufficient interest to warrant being recorded and the present paper is concerned mainly with the evidence for the instability and linkage of the characters in Z173.

\section{Methods}

Cultures were grown in nutrient broth (Oxoid No. 2) and colonies were screened for lactose fermentation on MacConkey agar (Oxoid No. 2). Screening of colonies for resistance to silver nitrate $(40 \mu \mathrm{g} / \mathrm{ml})$ and measurement of minimum inhibitory concentrations of the compound was done with a salt-free agar medium (McHugh et al, 1975).

Experiments to detect transfer of silver resistance were conducted in Brain Heart Infusion Broth (Difco) using as a recipient a strain of Escherichia coli (M2243) which was ONPG negative, resistant to nalidixic acid, and auxotrophic for histidine and several other amino acids.

Organisms were preserved by drying and were stored in air for short-term and in vacuo for longterm maintenance (Annear and Grubb, 1973).

\section{Results}

A colony of Z173 was checked for silver resistance, cultured in broth, and spread on a MacConkey plate which was incubated at $30^{\circ} \mathrm{C}$ for 20 hours. The majority of the resulting colonies were bright red, indicating rapid lactose fermentation, and were mucoid in texture; the remainder were pale pink, non-mucoid, and smaller than the rapid lactose fermenters. The pale pink colonies assumed a deeper red after several days of further incubation and were shown to be ONPG positive as were the rapid fermenters. Single colonies of the rapid fermenters were transferred to tubes of broth which were cultured at $30^{\circ} \mathrm{C}$. The cultures were sampled periodically and spread for the single colonies on MacConkey plates. During a period of 10 days the fraction of rapid lactose fermenters fell from a level of approximately $90 \%$ to one of $<1 \%$.

Screening of the colonies on silver plates by multipoint replication (Annear and Grubb, 1972) during these experiments revealed a firm linkage of silver resistance with rapid lactose fermentation and mucoid colony structure. No exceptions were found in tests with 500 colonies of each category of lactose fermenter.

The minimum inhibitory concentration of silver nitrate for the rapid lactose fermenters was $>1000$ 
$\mu \mathrm{g} / \mathrm{ml}$ whereas that for the slow lactose fermenters was approximately $25 \mu \mathrm{g} / \mathrm{ml}$. The values were obtained for both heavy and light inocula $\left(10^{6}\right.$ and $10^{2}$ organisms respectively).

When silver sensitive, slow lactose fermenting variants were grown in broth and stored for several weeks at room temperature, colony screening revealed no reversion to either silver resistance or rapid lactose fermentation.

In attempts to transfer silver resistance, a cross was set up using log phase cultures of the donor and the recipient in a ratio of approximately 1:100. After 20 hours at $37^{\circ} \mathrm{C}$ the mating mixture and appropriate controls were spread over salt-free MacConkey medium containing nalidixic acid (50 $\mu \mathrm{g} / \mathrm{ml})$ and silver nitrate $(50 \mu \mathrm{g} / \mathrm{ml})$. No transfer of either silver resistance or rapid lactose fermentation was obtained.

\section{Discussion}

The high frequency with which the linked characteristics of silver resistance and rapid lactose fermentation are lost in broth cultures of Z173 is strong evidence for an extrachromosomal (plasmid) location of the determinants concerned. The mucoid colony structure which accompanies these features is probably not governed by a separate determinant but is the consequence of the active lactose metabolism.

Although these determinants are spontaneously and rapidly lost during storage in broth culture, they are apparently not transmissible and are thus of a non-conjugative type. Since both parent and variant cells are ONPG positive and thus contain $\beta$-galactosidase which attacks lactose, it seems likely that the variants are lacking the permease activity which governs the entry of the carbohydrate into the cells. A 'cryptic' mutant of $E$. coli showing this property was reported by Herzenberg (1959) in his comprehensive study of the subject.

Silver resistance has been described previously in bacteria isolated from patients in other Burns Units. Rosenkranz et al (1974) reported it in isolates of Enterobacter cloacae where resistance to silver was manifested when the metal was tested as silver sulphadiazine or as silver benzoate but not as silver nitrate. Attempts to demonstrate transferable resistance in these strains gave negative results. McHugh et al (1975) discovered resistance to silver nitrate in isolates of Salmonella typhimurium and demonstrated the determinant together with those for resistance to a number of other metals and antibiotics to be transferable to sensitive recipients of $E$. coli and $S$. typhimurium. Neither group of these workers reported on tests for instability of the resistance determinants.
Williams-Smith and Parsell (1975) have recent $\frac{?}{8}$ reviewed work concerning the transmissibility of determinants for substrate utilization and other bi chemical activities used to differentiate bacterigenera and species. The present study has shown the likelihood of the permease for lactose fermentation in Z173 to be extrachromosomal and unstable bü not apparently transmissible.

The close biochemical similarity between $\mathrm{Z} 173$ arff $\mathrm{Z} 147$ and their recovery from patients in the sane area of the hospital suggest that the isolates are genetically related. It is possible that a dissociation may have occurred in the usually firm linkage between the determinants for silver resistance and lactose fermentation, thus yielding a slow lactose fermenter with unstable silver resistance. Further sampling of specimens for these organisms may have been rewarding in this respect.

Although a considerable amount of work has been done on the transmissibility and instability of genetie determinants in Gram-negative bacilli it appears the these two phenomena are rarely studied in parallet and there is a need for examination of the relation ship between them. Studies in progress with the present isolates are being directed along these chare nels and include further work with antibiotic resis tance determinants which they harbour but which have not been reported here Some preliminaro experiments have shown that these determinant? unlike that for silver resistance, are readily $\operatorname{tran} \overrightarrow{5}$ missible.

In view of the work of Rosenkranz et al (1974) would be of interest to carry out studies on the resistance of the present isolates to other silver coms pounds particularly silver sulphadiazine which used in this hospital and also widely elsewhere fow. the topical treatment of bacterial infection.

The clinical significance of the findings presente here is yet to be elucidated. However, it seems that while the use of silver compounds may well result in the selection of silver resistant organisms, spons taneous loss of such resistance occurs readily in the absence of the selective pressures. As yet this has been observed only in vitro but may possibly occuin also in in vivo.

\section{References}

Annear, D. I. and Grubb, W. B. (1972). Linked and unstablब resistance to kanamycin and penicillin, and diffusible pigment production, in an isolate of Staphylococcus aureus. J.D med. Microbiol., 5, 109-111.

Annear, D. I. and Grubb, W. B. (1973). Preservation od Staphylococcus aureus with unstable antibiotic resistance bo drying.J. Hyg. (Camb.), 71, 411-416.

Herzenberg, L. A. (1959). Studies on the induction of $\beta_{O}$ galactosidase in a cryptic strain of Escherichia colt. Biochem. biophys. Acta (Amst.), 31, 525-538. 
McHugh, G. L., Moellering, R. C., Hopkins, C. C., and Swartz, M. N. (1975). Salmonella typhimurium resistant to silver nitrate, chloramphenicol, and ampicillin. Lancet, 1, 235-240.

Rosenkranz, H. S., Coward, J. E., Wlodkowski, T. J., and Carr, H. S. (1974). Properties of silver sulfadiazine- resistant Enterobacter cloacae. Antimicrob. Agents Chemother., 5, 199-201.

Williams-Smith, H. and Parsell, Z. (1975). Transmissible substrate-utilizing ability in Enterobacteria. J. gen. Microbiol., 87, 129-140.

\section{Reports and Bulletins prepared by the Association of Clinical Biochemists}

The following reports and bulletins are published by the Association of Clinical Biochemists. They may be obtained from The Publishing Department, British Medical Journal (ACB Technical Bulletins), B.M.A. House, Tavistock Square, London WC1H 9JR. Overseas readers should remit by British Postal or Money Order.

SCIENTIFIC REPORTS (price $£ 1.00 / \$ 2.00$ each)

3 Automatic Dispensing Pipettes: an assessment of 35 commercial instruments September 1967 P. M. G. BROUGHTON, A. H. GOWENLOCK, G. M. WIDDOWSON, and K. A. AHLQUIST

4 An Evaluation of five Commercial Flame Photometers suitable for the Simultaneous Determination of Sodium and Potassium March 1970 P. M. G. BROUGHTON and J. B. DAWSON

SCIENTIFIC REVIEWS (price $£ 1.00 / \$ 2.00$ each)

1 The Assessment of Thyroid Function March 1971 F. V. FLYNN and J. R. HOBBS

2 Renal Function Tests Suitable for Clinical Practice January 1972 F. L. MTTCHELL, N. VEALL, and R. W. E. WATTS

3 Biochemical Tests for the Assessment of Fetoplacental Function May 1975 C. E. WILDE and R. E. OAKEY

TECHNiCAL BULLETINS (price $£ 1 \cdot 00 / \$ 2.00$ each)

9 Determination of Urea by AutoAnalyzer November 1966 RUTH M. HASLAM

11 Determination of Serum Albumin by AutoAnalyzer using Bromocresol Green October 1967 B. E. NORTHAM and G. M. WIDDOWSON

13 An Assessment of the Technicon Type II Sampler Unit March 1968 B. C. GRAY and G. K. McGOWAN

14 Atomic Absorption Spectroscopy: an outline of its principles and a guide to the selection of instruments May 1968 J. B. DAWSON and P. M. G. BROUGHTON

15 A Guide to Automatic Pipettes (2nd edition) June 1968 P. M. G. BROUGHTON

16 A Guide to Automation in Clinical Chemistry May 1969 P. M. G. BROUGHTON

17 Flame Photometers: a comparative list of 17 instruments readily available in Britain August $1969 \mathrm{P}$. WIIDING

19 Spectrophotometers: a comparative list of low-priced instruments readily available in Britain May 1970 C. E. WILDE and P. SEWELI
20 Quantities and Units in Clinical Biochemistry June 1970 P. M. G. BROUGHTON

21 Filter Fluorimeters: A comparative list of 18 instruments September 1970 H. BRAUNSBERG and s. s. BROWN

22 Bilirubin Standards and the Determination of Bilirubin by Manual and Technicon AutoAnalyzer Methods January 1971 BARBARA BILLING, RUTH HASLAM, and N. WALD

23 Interchangeable Cells for Spectrophotometers and Fluorimeters September 1971 S. S. BROWN and A. H. GOWENLOCK

24 Simple Tests to Detect Poisons March 1972 B. w. MEADE et al.

25 Blood Gas Analysers May 1972 K. DIxoN

26 Kits for Enzyme Activity Determination September 1972 S. B. ROSALKI and D. TARLOW

27 Assessment of Pumps Suitable for Incorporation into Existing Continuous Flow Analytical Systems November 1972 A. FLECK et al.

28 Routine Clinical Measurements of Transferrin in Human Serum September 1973 K. DIXON

29 Control Materials for Clinical Biochemistry (5th edition) September 1973 J. F. STEVENS

30 Notes on the Quality of Performance of Serum Cholesterol Assays September 1973 s. s. BROWN

31 Determination of Uric Acid in Blood and in Urine July 1974 R. W. E. WATTS

32 A Survey of Amino Acid Analysers Readily Available in the United Kingdom September 1974 J. E. CARLYLE and P. PURKISS

33 Definitions of some Words and Terms used in Automated Analysis November 1974 A. FLECK, R. ROBINSON, S. S. BROWN, and J. R. HOBBS

34 Measurement of Albumin in the Sera of Patients January 1975 LINDA SLATER, P. M. CARTER, and J. R. HOBBS

35 Investigation of the Validity of Temperature Correction Factors for Serum Aspartate and Alanine Transaminases March 1975 s. B. ROSALKI et al.

36 Factors Influencing the Assay of Creatinine, November 1975 J. G. H. COOK 